means in higher education. Moreover, the essence of Kaizen conception has been specified; the peculiarities of forming innovation-oriented professional environment based on sustainable use of resources of a higher technical educational institution due to implementation of experimental monitoring technology for training future specialists based on lean production have been considered. Pedagogical reasonability of advanced training of future specialists at higher technical educational institution based on the idea of lean manufacturing has been proven.

Keywords: higher technical educational institution, training, Kaizen philosophy, educational audit, lean manufacturing.

Подано до редакиії 24.06.2016

UDC: $371.5 .036: 78$

Do Han Feng,

post-graduate student, Department of Music Art and Choreography, South Ukrainian National Pedagogical University named after K. D. Ushynsky,

4, Fontanska doroha Str., Odesa, Ukraine

\title{
SPECIFICITY OF PREPARING SCHOOLCHILDREN FOR COLLECTIVE INSTRUMENTAL MUSIC-MAKING AT COMPREHENSIVE SCHOOL
}

The paper is focused on the study of specificity of preparing pupils for collective instrumental music-making at a comprehensive school. In particular, age peculiarities of primary school children and adolescents, peculiarities of selection of pupils for learning to play musical instruments and issues of choosing proper instruments for collective music-making have been considered. Particular attention is paid to organizing performances of instrumental ensembles in the pedagogical process of a comprehensive school, in particular, the importance of organizing individual, selfguided and group studies, teaching fundamentals of basic musical theory as well as pupils' participation in artistic and creative collective activities at a comprehensive school.

Keywords: comprehensive school, instrumental ensemble, performance activities.

Problem statement. The future of society depends largely on the improvement of intellectual, cultural and creative potential of the younger generation, which is formed under the influence of socio-cultural environment. The formation of a creative personality is influenced to a great extent by harmonious composition of the programme for schoolchildren's development, by the teaching staff and particularly the teacher as well as by teaching forms and methods used in the educational process of a comprehensive school.

There are continuous debates in the educational environment concerning integration of some new forms into training and educational process of a comprehensive school, which must be oriented at schoolchildren's balanced development. At the same time, among a great number of rather practical proposals on improvement of the educational process in the above mentioned branch of education, the use of successful pedagogical experience of Western countries in the development and implementation of artistic and creative capacity of a child has hardly ever been offered. In particular, it is referred to the use of forms of regular collective instrumental music-making. Therefore, the above mentioned issue is quite relevant for both theory and practice of music and aesthetic education of schoolchildren in the countries of Eastern Europe and the Far East.

Review of recent researches and publications. Review of scholarly literature has shown that artistic and aesthetic development of schoolchildren has been consi- dered in several directions. For instance, much attention is paid to the integration of scholarly research results concerning artistic culture into the educational process of comprehensive schools (O. Haidamaka, O. Kalinichenko, L. Masol, I. Rudenko and others). The issue of vocal and choral education of schoolchildren was considered by O. Apraksina, L. Vengrus, A. Kozyr, H. Stulova and others. However, the issue of implementing pupils' collective instrumental artistic performance into the teaching process of a comprehensive school and its potential effect on schoolchildren's development still remains understudied. This very issue is being considered in the author's thesis research performed according to the research plan of South Ukrainian National Pedagogical University named after K. D. Ushynsky.

The aim of the paper is to consider the specificity of preparing pupils for collective instrumental artistic performance at a comprehensive school based upon experience of foreign music education.

Major content. When dealing with the chosen issue, first of all, it is necessary to consider the following aspects: 1) pupils' age peculiarities, which affect the content and forms of lessons; 2) the choice of best possible instruments appropriate for collective music-making in training and educational process of a comprehensive school; 3) principles of organization of learning and performing activities of an instrumental ensemble in the pedagogical process of a comprehensive school. 
According to the existing methods of teaching playing musical instruments, teaching to play orchestral instruments can be started at the age of 7-12 years old (depending on the chosen instrument). There are situations when children start attending music classes at the age of six. In this case, it is better to begin with a recorder, a sopilka or any other folk or historical wind instrument. After that, the teacher can continue gradually with professional orchestral musical instruments.

In order to determine the necessity of age-specific and individual approach to a pupil, it should be mentioned that at every age period of child development corresponding methods of education should be used. For this purpose, let us consider the peculiarities of primary school age and adolescence as long as at this very age it is reasonable to engage children into collective instrumental artistic performance.

It is known that younger schoolchildren are the children aged from 6 to 11 years old attending 1-4 years of study at a comprehensive school. This is the age period when childhood comes to end. In the course of mastering the new type of learning, artistic and creative activities, junior schoolchildren spend much time and energy on playing. These activities facilitate the development of their relationships with age mates and adults, their mental development; personal mental life acquires new features; new mental formations are being developed, so that children get to the new level of self-understanding and understanding the world. They discover new opportunities and horizons [1].

The peculiarity of children's mental health is their cognitive activity. Their cognitive need is constantly focused on cognition and formation of their own view of the environment. When playing, a child experiments, tries to establish causal relationships and dependencies. When facing some problems, a child tries to solve them imagining a real situation and acting in it in his/her imagination. The type of thinking when a problem is solved as a result of inner actions with images is called eye-minded thinking. Visual thinking is a major type of thinking in primary school age [2, p. 4].

Adolescence is defined in psycho-pedagogical literature as the age from 11-12 to 14-15 years. It corresponds to middle school age (5-9 years of study at comprehensive school). This peculiarity is manifested in physical, mental, moral, social and spiritual development of a personality. Emergence of new personal qualities is followed by complications in the process of adolescents' upbringing as long as they often demonstrate disobedience and objection in different forms against authorities that were effective at the former stage of ontogenesis [1].

The most important phenomenon at this age is the formation of self-consciousness, which is characterized, first of all, by considering oneself to be an adult [3]. However, an adolescent is not mature enough. He/she only feels drastic changes in the attitude towards the society and tends to gain the status of an adult [4]. For this reason, only the specially organized activities can create situations, in which relationships between adolescents and adults correspond to demands and ambitions of adolescents. Close personal communication becomes the most important type of activities in this period.

Thus, it is necessary to engage pupils into collective music making in the pedagogical process of a comprehensive school with account of age-specific and psychological peculiarities of schoolchildren. One more important step in organizing a musical band is revealing pupils' capabilities for mastering a musical instrument. First of all, every member of an instrumental ensemble should have an ear for music, which is the basis for human musicality.

With the aim of revealing schoolchildren's ear for music, they are offered to sing their favourite song or separate sounds of different pitch played by the teacher on the piano or other musical instrument. In this case, quite an accurate reference point is the capability to distinguish between the intervals of major and minor second. If a pupil distinguishes between tone and semitone intervals easily, he/she is considered to have ear for distinguishing sound pitch that is appropriate for further classes. Testing harmonious hearing involves determining, how many sounds a future participant of a musical ensemble can hear in a chord stricken at once, and if he/she can repeat each of them separately. The level of aural musical memory is identified according to precision of memorizing and reproducing a small musical phrase. Sense of rhythm is checked by the ability to repeat precisely the certain metre-rhythmical structure of a sounded melody. Of course, musical capabilities can and should be developed until the necessary level is achieved due to the use of a certain system of education and training.

The necessary capabilities, even being combined efficiently, are of no effect, if a future musician does not have basic skills of playing a musical instrument. In particular, the most important is mastering comfortable position of an instrument, skills of natural, focused, economical work of organs participating in playing. Pupils' capability to participate in collective music-making depends greatly on proper acquisition of basic technical skills (the so-called performance position), on persistent, conscious work on their perfection and reinforcement.

Playing wind instruments requires not only musical capabilities, but certain physical qualities. When selecting schoolchildren who are going to learn to play wind musical instruments, it is necessary to make sure that a future ensemble participant has healthy upper respiratory tracts, eyes, ears; no chronic diseases of heart of any other internal organs. Analyzing pupils' physical qualities significant for playing wind instruments, it is necessary to pay attention to the structure and shape of their lips. The most appropriate are middle fullness lips with no congenital defects of acquired traumas. The tongue is also important for a participant of a wind ensemble. The size and shape of the tongue is checked according to the easiness and accuracy of pronouncing letters when talking. Suitable are the candidates with the flexible, not too massive tongue of normal length. Arms and fingers length is not of substan- 
tial significance for playing wind instruments, except for trombone. It is essential to make sure that pupils' hands are capable of shortening and their fingers can move easily and with the required rate.

Moreover, it is reasonable to consider the level of general development of a schoolchild, his/her quick understanding, cognitive need, profound emotional response, subtlety of perception, initiativity and other individual qualities.

Considering all the above mentioned, we have concluded that the most appropriate instrument for mastering by primary school pupils is a recorder. This instrument can be used efficiently in the process of collective musicmaking. It is easy to master compared to the other aerophones. Its attractive quality is light weight and relatively low cost available for a pupil's family or a school. One can perform music pieces of different difficulty levels on it, use it as an instrument for a leading melody part or as an accompanying instrument. However, it is good for some high school children to master more complicated musical instruments - oboe, clarinet, saxophone, trumpet, etc. A variety of instruments offers new opportunities for learning diverse musical repertoire and is beneficial for the whole ensemble.

It should be noted that children who experience problems with identifying sound pitch of have chronic diseases of respiratory tracts, etc. can participate in ensemble music-making performing the part of a percussion instrument.

It is quite difficult to organize the work of an instrumental ensemble in training and education process of a comprehensive school. For instance, in Ukraine, such subjects as "Orchestral class" or "Instrumental ensemble" are not included in the compulsory curriculum. However, the work of pupils' instrumental ensemble as extracurricular activity is quite possible.

Extracurricular and after-school activities are based on the following principles: a) absolutely free-will participation of all the pupils in musical and performing activities; b) free choice of activities without compulsion and under conditions of such a choice; c) free termination of participation without any "academic consequences" for the member of the ensemble [6].

The remarkable thing is that the sphere of extracurricular activities, as noted by experts, is more conventional that the educational sphere as long as it is impossible to change quickly the living customs, traditions, norms of existence and relaxation, habits [7, p. 11].

In fact, the best organizer of a performing group of primary school children and adolescents (fist of all, recorder ensemble is meant) as extracurricular activities should be the teacher of music who was trained in the class for wind instruments and obtained additional major as a teacher of instrumental ensemble.

It should be noted that organizing a musical ensemble and working with it is quite a difficult process. It is not limited by collective rehearsal music-making (for example, twice a week). It is also necessary to introduce fundamentals of basic musical theory to children in an understandable form and to the appropriate extent, organize individual and self-guided classes, plan and implement concert and performing activities of the ensemble.

It is necessary to begin classes with the leader's fundamental explanation how to breathe in with simultaneous demonstration. This work is organized individually with each pupil. In order to make these classes easy, efficient and interesting for pupils, the teacher should have fair knowledge of the peculiarities of sounding on the instrument. First classes are the important factor as long as they determine further work of the ensemble to a great extent, in particular, interest, determination, carefulness of pupils. One more peculiarity of working with amateur pupil's ensemble is the fact that the material should be represented to each participant separately with further use of the obtained theoretical knowledge in practice. In particular, it is essential to learn various note length from the very beginning: at first, empirically, on the examples; then - theoretically and afterwards - in the course of studying ensemble parts. After that, it is necessary to study the system of organizing sound pitch and gamut (musical sequence of sounds).

General classes are conducted only after consolidation of the material during individual work with each pupil. Learning primary material can last from several days to several weeks. And only after the majority of participants have learned this material, orchestral and ensemble work can be started. The pupils who have not acquired it are not engaged into collective work and work individually with the leader or work on their skills themselves.

Orchestral and ensemble work starts form collective performing gamut that has been learned by students themselves indicated with the leader's hand. Gamut is performed with the use of various length (from semibreve to semiquaver) and with various dynamic inflexions (from $p p$ to $f f$ ). Therewith, children start to learn pieces of music performed by all the ensemble members in unison. After such type of music-making that lasts for some time, pupils continue gradually with learning and collective performing of orchestral parts.

In order to introduce the first orchestral piece of music to musicians-beginners, first of all, the leader should choose quite a simple piece with the elements that the children have learned before and understand theoretically. Members of the orchestra should master their first pieces of music easily and perform them successfully. Gradually, intonational material, which is new for the pupils, is introduced. At general rehearsals, the leader facilitates revision of the material learned before, playing and tuning the instruments. These elements make the compulsory component of every class [8].

After that, work on the chosen piece of music starts. At first, the leader explains, how the participants must learn this piece of music. The latter is learned and the parts are checked in the group of accompaniment, then - in the group that is committed to perform the main intonational material (relief). Afterwards, the above mentioned groups are joined 
by the one performing secondary relief functions (second parts) if it is supposed to be according to the pattern. Every part of the piece of music, sometimes even every bar, is performed for several times for masterful playing and consolidation of the material learned. After the ensemble have learned to perform the piece of music more or less masterfully, the leader can continue with the other one that should differ for the previous one in the genre, style, imaginative manner of performing. It is desirable that it is less complicated in terms of technique.

Conclusions and prospects for further research. Thus, considering the importance of musical and aesthetic development of the younger generation, current state of comprehensive school functioning and corresponding prospects for organizing instrumental musical ensemble at a comprehensive school, it should be noted that a comprehensive school has all the opportunities to prepare pupils for collective instrumental music-making under conditions of extracurricular activities. The assessment of psychological and age peculiarities of pupils of primary and middle school age, ordinary level of the development

\section{ЛІТЕРАТУРА}

1. Савчин М. В. Вікова психологія : [навч. посіб.] / М. В. Савчин, Л. П. Василенко. - К. : Академвидав, 2005. - $360 \mathrm{c}$.

2. Казанкова Н. П. Педагогічна майстерня (методичні розробки викладачів ПСМНЗ Донецької області) / Н. П. Казанкова, С. Ю. Яровенко. - Донецьк : ДОУМЦК, 2007. - 44 с.

3. Кон И. С. Психология ранней юности : кн. для учителя / Кон И. С. - М. : Просвещение, 1989. - 252 с.

4. Проблемы психологии современного подростка : сб. науч. тр. / Ред. Д. И. Фельдштейн - М. : АПН СССР, $1982-160 \mathrm{c}$.

5. Фридман Л. М. Психологический справочник учителя / Л. М. Фридман, И. Ю. Кулагина - М. : Просвещение, 1991. - 288 с.

\section{REFERENCES}

1. Savchyn, M. V., \& Vasylenko, L. P. (2005). Vikova psykholohiia [Developmental psychology]. Kyiv: Akademvydav [in Ukrainian].

2. Kazankova, N. P., \& Yarovenko, S. Yu. (2007). Pedahohichna maisternia [Pedagogical workshop]. Donetsk: DOUMTsK [in Ukrainian].

3. Kon, I. S. (1989). Psikhologiya ranney yunosti [Psychology of early youth]. Moscow: Prosveschenie [in Russian].

4. Feldshteyn, D. I. (Ed.). (1982). Problemy psikhologii sovremennogo podrostka [Problems of contemporary adolescents' psychology]. Moscow: APN SSSR [in Russian].

5. Fridman, L. M., \& Kulagina, I. Yu. (1991). Psikhologicheskiy spravochnik uchitelya [Psychological reference-book of a teacher]. Moscow: Prosveschenie [in Russian].

6. Plokhotniuk, O. S. (2006). Formuvannia tsinnisnykh oriientatsii pidlitkiv u suchasnykh formakh of their musical capabilities as well as financial capacity of a family and a school makes it possible to state that the most available and effective instrumental band, from musical and pedagogical point of view, is recorder ensemble. If possible, this ensemble can be joined by groups of classical or folk aerophones, string and percussion instruments. Such an approach allows contemporary school pupils with no musical education to participate in exciting, attractive, useful collective music-making, which facilitates development of musical and aesthetic capabilities, emotional sphere, mental performance, realization of children and adolescents' need for artistic and creative activities and communication.

These conclusions can be developed and specified in the following directions: determining the character of the initial repertoire of the ensemble, principles of its expansion; methods of work on basic skills of playing the recorder; principles and methods of applying the same skills in mastering orchestral wind instruments; methods of achieving ensemble harmony of the parts, etc.

6. Плохотнюк О. С. Формування ціннісних орієнтацій підлітків у сучасних формах позанавчальної діяльності / О. С. Плохотнюк // Вісн. Луган. нац. пед. ун-ту імені Тараса Шевченка : Педагогічні науки. 2006. - Ч. 2, № 8 (103). - С. 155 - 159.

7. Орлов Г. П. Свободное время : свободное развитие человека и мера общественного богатства / Г. П. Орлов. - Свердловск : Кн. Изд-во, 1989. - 176 с.

8. Плохотнюк О. С. Творчість В. Квітки в контексті функціонування народного самодіяльного дівочого духового оркестру «Роксолана» / О.С. Плохотнюк, Н. С. Маліченко // Історія становлення та перспективи розвитку духової музики в контексті національної культури України та зарубіжжя : матеріали VIII Всеукр. наук.-практ. конф., 23-24 квітня 2016 р. - Рівне : Волинські обереги, 2016. - С. 80 - 87.

pozanavchalnoi diialnosti [The formation of axiological orientation of adolescents in contemporary forms of afterschool activities]. Visnyk Luhanskoho natsionalnoho pedahohichnogo universytetu imeni Tarasa Shevchenka: Pedahohichni nauky - Bulletin of Luhansk National Pedagogical University named after T. Shevchenko, 8 (103), 155 - 159. (Pt. 2) [in Ukrainian].

7. Orlov, G. P. (1989). Svobodnoe vremya: svobodnoe razvitie cheloveka i mera obshchestvennogo bogatstva [Free time: free development of a person and the degree of social wealth]. Sverdlovsk: Kn. Izd-vo [in Russian].

8. Plokhotniuk, O. S., \& Malichenko, N. Ye. (2016). Tvorchist V. Kvitky $\mathrm{V}$ konteksti funktsionuvannia narodnoho samodiialnoho divochoho dukhovoho orkestru „Roksolana” [Creative work by V. Kvitka in the context of activities of folk amateur female wind orchestra "Roksolana”]. Istoriia stanovlennia ta perspektyvy rozvytku 
dukhovoi muzyky v konteksti natsionalnoi kultury Ukrainy ta zarubizhzhia - History of formation and prospects for development of wind music in the context of national culture of Ukraine and foreign countries: Proceedings of VIII All-Ukraine research and practice conference. (pp. 80 - 87). Rivne: Volynski oberehy [in Ukrainian].

\section{Ду Хань Фен, \\ аспірант кафедри музичного мистеитва та хореографії, Південноукраїнський наџіональний педагогічний університет імені К. Д. Уиинського, вул. Фонтанська дорога, 4, м. Одеса, Украӥна}

\section{СПЕЦИФІКА ПІДГОТОВКИ УЧНІВ ДО КОЛЕКТИВНОГО ІНСТРУМЕНТАЛЬНОГО МУЗИКУВАННЯ В ЗАГАЛЬНООСВІТНІЙ ШКОЛІ}

У статті автор проаналізував специфіку підготовки учнів до колективного інструментального виконавства в загальноосвітній школі. Зокрема, розглянуто вікові особливості учнів молодшого шкільного віку і підлітків, а також питання підбору учнів для навчання грі на музичному інструменті та вибору відповідного інструменту для організації ансамблевої музичної діяльності учнів. Автор дійшов висновку, що в загальноосвітній школі $\epsilon$ всі можливості для підготовки учнів до колективного інструментального виконавства в умовах позаурочної діяльності. Оцінка психологічних та вікових особистісних властивостей учнів раннього і середнього шкільного віку, звичайного рівня розвитку їхніх музичних здібностей, знань і умінь, а також матеріальних можливостей пересічної школи та сім'ї дає підстави стверджувати, що найбільш доступним і ефективним з музичнопедагогічної точки зору інструментальним колективом $€$ ансамбль блок-флейтістів. За наявності в школі учнів, які володіють іншими музичними інструментами, такий ансамбль може бути доповнений групами класичних або народних духових, струнних і перкусійних інструментів. Такий підхід дає можливість багатьом учням загальноосвітніх шкіл, які не отримують спеціальної музичної освіти, брати участь в захоплюючому, привабливому, корисному для кожного колективному музикуванні, яке сприяє розвиткові не тільки музично-естетичних здібностей, але й також емоційної сфери, інтелектуального потенціалу, реалізації потреби дітей і підлітків в художньо-творчій діяльності та спілкуванні.

Ключові слова: загальноосвітня школа, інструментальний колектив, виконавська діяльність.

\section{Ду Хань Фэн, аспирант кафедры музыкального искусства и хореографии, Южноукраинский национальный педагогический университет имени К. Д. Уиинского, ул. Фонтанская дорога, 4, г. Одесса, Украина}

\section{СПЕЦИФИКА ПОДГОТОВКИ УЧАЩИХСЯ К КОЛЛЕКТИВНОМУ ИНСТРУМЕНТАЛЬНОМУ МУЗИЦИРОВАНИЮ В ОБЩЕОБРАЗОВАТЕЛЬНОЙ ШКОЛЕ}

В статье автор проанализировал специфику подготовки учеников к коллективному инструментальному исполнительству в общеобразовательной школе. В частности, рассмотрены возрастные особенности учеников младшего школьного возраста и подростков, особенности подбора учащихся для обучения игре на музыкальном инструменте и выбора соответствующего инструмента для организации ансамблевой музыкальной деятельности учащихся. Автор пришел к выводу, что в общеобразовательной школе есть все возможности для подготовки учащихся к коллективному инструментальному исполнительству в условиях внеурочной деятельности. Оценка психологических возрастных личностных свойств учащихся раннего и среднего школьного возраста; обычного уровня развития их музыкальных способностей, знаний и умений; а также материальных возможностей среднестатистической школы и семьи позволяет утверждать, что наиболее доступным и эффективным с музыкально-педагогической точки зрения инструментальным коллективом является ансамбль блок-флейтистов. При наличии в школе учеников, владеющих другими музыкальными инструментами, такой ансамбль может быть дополнен группами классических или народных духовых, струнных и ударных инструментов. Такой подход дает возможность многим ученикам общеобразовательных школ, не получающим специальное музыкальное образование, участвовать в увлекательном, интересном, полезном для каждого коллективном музицировании, которое способствует развитию не только музыкально-эстетических способностей, но также эмоциональной сферы, интеллектуального потенциала, реализации потребности детей и подростков в художественно-творческой деятельности и общении.

Ключевые слова: общеобразовательная школа, инструментальный коллектив, исполнительская деятельность.

Подано до редакції 25.06.2016

Реценизент: д. мистецтвознавства, проф. С. В. Шип 